Journal of Applied Finance \& Banking, Vol. 12, No. 2, 2022, 1-25

ISSN: 1792-6580 (print version), 1792-6599(online)

https://doi.org/10.47260/jafb/1221

Scientific Press International Limited

\title{
Exploring the Determinants of Company's Dividend Payout Policy in Vietnamese Stock Market
}

\author{
Cheng-Wen Lee ${ }^{1}$, Hui-Hsin Hsu ${ }^{2 *}$, San-Jung Peng ${ }^{3}$, \\ and Tuyet Nhu Huynh Nguyen ${ }^{4}$
}

\begin{abstract}
Vietnamese stock market exists in one of the most dynamic emerging countries in East Asia. As expected, stock market has worked well to push up Vietnamese economy. Due to the information asymmetry, investors often rely on the dividend payment as an indicator to predict the company's future prospects. Dividend payout policy is a significant concern of financial managers' in shareholding firms and outside investors' decision-making. The aim of dividend payout policy is to allocate retained earnings for reinvestment and dividends for shareholders. This research investigates the determinants of dividend payout policy in Ho Chi Minh Stock Exchange in Vietnam, an emerging stock market that was officially established in July, 2000. Additionally, this research evaluates whether the factors affect company's dividend policy such as profitability, firm size, financial leverage and growth rate, etc. This research data is collected from enterprises listed on the Vietnam stock market in the period of 2014-2018 with 756 observations, and analyzed by Ordinary Least Square model and Fixed Effect model and Random Effect model. Based on the Hausman Specification Test result, Fixed Effect model is the most consistent model of examining the factors affecting the dividend payout policy.
\end{abstract}

JEL Classification: C22, E27, G15.

Keywords: Dividend payout policy, Vietnamese stock market, Ordinary least square, Fixed effect model.

${ }^{1}$ Department of International Business, College of Business, Chung Yuan Christian University, Taoyuan City, Taiwan

2* Ph.D. Program in Business, College of Business, Chung Yuan Christian University, Taoyuan City, Taiwan. Corresponding author.

${ }^{3}$ Department of Business Administration, College of Business, Chung Yuan Christian University, Taoyuan City, Taiwan.

${ }^{4}$ International Master Program of Business Administration, College of Business, Chung Yuan

Christian University, Taoyuan City, Taiwan

Article Info: Received: January 17, 2022. Revised: January 26, 2022.

Published online: January 31, 2022. 


\section{Introduction}

Dividend payment is the distribution of net profit after tax to a company's shareholders after keeping a specific amount of earnings to reinvest in the business. Dividend policy is one of the most important decision in financial management of company. Companies must makes a choice as to what part of the profit to retain and to spend on investment, development and how much of it to transfer to shareholders. Decision on the distribution rate between retained earnings and profit using to pay for dividends to shareholders expresses through the dividend payout policy. Retaining part of the company's profit and its uses as a source of financing of development projects contributes to the increase in the value of such an entity, and thus leads to an increase in the value of its share (Sierpinska and Jachna, 2007). In order to make a reasonable dividend payment decision, enterprises need to consider many factors.

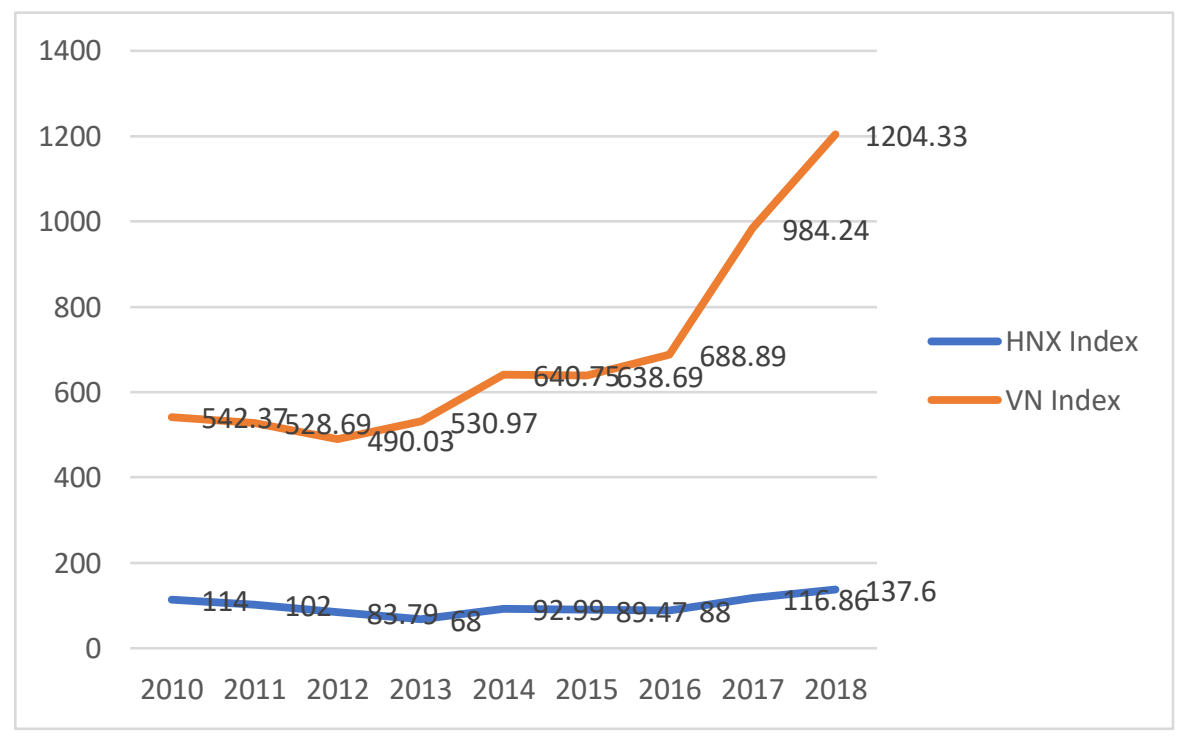

Figure 1: Performance of VN-Index and HNX-Index (2010-2018)

The stock market has appeared in the world for centuries, but it was only established in Vietnam market more than 20 years ago. It started with the establishment of the State Securities Commission - the regulator over the securities market in 1997. Vietnam stock market includes Ho Chi Minh Stock Exchange (HOSE) - Vietnam's largest stock exchange and Hanoi Stock Exchange (HNX). In the initial stage of the stock market, with the establishment of Ho Chi Minh Stock Exchange on 20th July in 2000, there was only two listed company with total capitalization of VND986 billion (amounting to $0.28 \% / G D P$ (Gross Domestic Product) in 2000). On July 20th 2000, the Ho Chi Minh City Securities Trading Center officially became operational and executed the first trading session on July 28th 2000 with 2 types of listing stocks. Ho Chi Minh City Securities Trading Center is also a place to list securities transactions of large companies. On the other hand, Hanoi Securities Trading Center 
is a place where listing of small and medium enterprises is concentrated. The Vietnam Stock Index (VN-Index) is a capitalization-weighted index of all the companies listed on the Ho Chi Minh Stock Exchange. The comparison between VN-Index and HNX-Index performance (2010-2018) is illustrated in Figure 1.

For the last 20 years, Vietnam's stock market has experienced a lot of changes, but it is also growing more and more strongly, through many different periods. The Vietnam stock market has grown significantly, at the beginning of the market in 2000. There were only 2 listed companies. However, on August 15, 2018, Ho Chi Minh Stock Exchange had 410 listed securities codes, including 361 stocks and 45 bonds. Vietnamese stock market started to develop rapidly in 2006. In the last 5 years, the market capitalization has increased rapidly with the growth rate of over $25 \%$. The number of listed companies in 2006 increased from 31 to 167, over 5 times higher than in 2005 (Table 1). The period from 2000 to 2005 marked the beginning of the stock market, or it was considered a toddler period. During this period, there are about 30 corporations listed in both stock exchanges, market capitalization reached just under $1 \%$ of GDP, almost no change at all. However, Vietnamese stock market started to develop rapidly in 2006.

Table 1: Number of listed firms in Vietnamese stock market (2005-2018)

\begin{tabular}{|l|l|l|l|l|l|l|l|l|l|}
\hline Year & $\mathbf{2 0 0 5}$ & $\mathbf{2 0 0 6}$ & $\mathbf{2 0 0 7}$ & $\mathbf{2 0 0 9}$ & $\mathbf{2 0 1 1}$ & $\mathbf{2 0 1 3}$ & $\mathbf{2 0 1 5}$ & $\mathbf{2 0 1 7}$ & $\mathbf{2 0 1 8}$ \\
\hline HSX & 23 & 81 & 107 & 175 & 275 & 284 & 307 & 344 & 373 \\
\hline HNX & 8 & 86 & 116 & 236 & 356 & 369 & 377 & 384 & 376 \\
\hline TOTAL & 31 & 167 & 223 & 411 & 631 & 653 & 684 & 728 & 749 \\
\hline
\end{tabular}

Source: collected from data of Ho Chi Minh Stock Exchange and Hanoi Stock Exchange

Through the period from 2006, when the Law on Securities was enacted and officially took effect from the beginning of 2007, it gradually improved the inadequacies, conflicts with other legal documents, and helped the market. Vietnam stock market has the ability to integrate more with international and regional capital markets. Vietnam's stock market becomes more transparent and safe, increasing the ability to manage and supervise state management agencies. In 2006, market size marked a strong leap when reaching $22.7 \%$ of GDP, and the figure even continued to increase strongly to over $43 \%$ in 2007 . Referring to "up there must be down", due to the influence of the financial market and the economy of the country and the world, 2008 is a year of "sad market" with market capitalization falling sharply, down to $18 \%$ of GDP. Through 2009, the market began to recover slightly with a market capitalization of $37.71 \%$ of GDP. Accompanying with this recovery, listed companies significantly increase in the market.

From 2013 to 2018, there are three sub-periods of tax policy on dividends and capital gains in Vietnam. From January 2013 to December 2018, individual investors' dividends and capital gains were exempt from income tax while Vietnamese institutional investors' capital gains were charged at the rate of $28 \%$ and foreign institutional investors' capital gains were taxed at $1 \%$ of selling price. 
In the second period, dividends and capital gains of individual investors were exempt from income tax from to January 2016 to December 2016; then, they were charged $5 \%$ and $20 \%$ or $0.1 \%$ of selling price respectively from January 2017 to July 2018. In addition, the tax rate for Vietnamese institutional investors' capital gains was reduced to $25 \%$. In the third sub-period, Vietnamese government reduced tax rates for individual investors' dividends and capital gains to $0 \%$ and by half respectively as a means to support individual investors in economic recession (Table 2).

Table 2: Vietnam tax policy on dividends and capital gains (2013-2018)

\begin{tabular}{|c|c|c|c|c|c|c|}
\hline & \multicolumn{2}{|c|}{ 1st sub-period } & \multicolumn{2}{c|}{ 2nd sub-period } & \multicolumn{2}{c|}{ 3rd sub-period } \\
\cline { 2 - 7 } & Dividends & $\begin{array}{c}\text { Capital } \\
\text { gains }\end{array}$ & Dividends & $\begin{array}{c}\text { Capital } \\
\text { gains }\end{array}$ & $\begin{array}{c}\text { Dividends } \\
\text { Capital } \\
\text { gains }\end{array}$ \\
\hline $\begin{array}{c}\text { Individual } \\
\text { investors }\end{array}$ & $0 \%$ & $0 \%$ & $0 \%$ and $5 \%$ & $\begin{array}{c}0 \%{ }^{\mathrm{a}} \text { and } 20 \% \\
\text { or } \\
0.1 \% \text { of selling } \\
\text { price }\end{array}$ & 0 & $\begin{array}{c}10 \% \\
\text { or } \\
0.05 \% \\
\text { of selling } \\
\text { price }\end{array}$ \\
\hline $\begin{array}{c}\text { Vietnamese } \\
\text { institutional } \\
\text { investors }\end{array}$ & $0 \%$ & $28 \%$ & $0 \%$ & $25 \%$ & $0 \%$ & $25 \%$ \\
\hline $\begin{array}{c}\text { Foreign } \\
\text { institutional } \\
\text { investors }\end{array}$ & $0 \%$ & $\begin{array}{c}0.1 \% \\
\text { of selling } \\
\text { price }\end{array}$ & $0 \%$ & $\begin{array}{c}0.1 \% \text { of selling } \\
\text { price }\end{array}$ & $0 \%$ & $\begin{array}{c}0.1 \% \\
\text { of selling } \\
\text { price }\end{array}$ \\
\hline
\end{tabular}

Source: Circular No.100/2004/TT-BTC, Law No.09/2003/QH11, Law No.14/2008/QH12, Law No.04/2013/QH12, Circular No. 134/2014/TT-BTC, Decree No.101/2018/ND-CP and Circular 160/2015/TT-BTC.

Note: 1st sub-period is from January 2013 to December 2015; 2nd sub-period is from January 2016 to July 2018; 3rd sub-period is from August 2018 to December 2018; a: from to January 2016 to December 2016; b: from January 2017 to July 2018.

And so far, market capitalization has skyrocketed to more than $82 \%$ of GDP, reflecting a boom in the stock market. The year 2017 has marked strong economic growth in the Unlisted Public Company Market (UPCoM), with GDP going up about 6-7\% and it keeps increasing. As a result, Vietnam recently has become Asia's fastest growing stock market with $100 \%$ growth in 5 years. The latest report compiled by the State Securities Commission shows that by the end of January 2019, there were 755 stocks and fund certificates listed across the market and 804 stocks registered on the UPCoM with total listing value of more than VND38.8 billion, up $26 \%$ compared to the end of 2017. In addition, market capitalization rose $12.7 \%$ compared to 2017 , accounting for $71.6 \%$ of the country's gross domestic product, exceeding the government's plan for 2020. Stock market is becoming the more remarkable capital mobilization channel for Vietnamese economy to push up national economic and maintain a high development speed. Consequently, Vietnam was the fifth nation within the ASEAN to acknowledge the derivatives market, 
alongside Singapore, Malaysia, Indonesia, and Thailand. The country was the $42^{\text {nd }}$ nation across the globe to acknowledge this market.

The stock market has brought great value and positive impacts to the Vietnamese economy. It is also an important capital mobilization channel to promote the development of enterprises and investors. However, the stock market is still a risky investment channel. Vietnamese market needs to continue to maintain and improve the criteria set-out within a minimum review period of one year. The recognition of FTSE Russell would help change the status of the national financial market, promise positive impact on its ability to attract foreign investment, as well as improve market liquidity, the quality of listed companies and motivation to further improve the legal framework.

Especially, due to the information asymmetry of Vietnamese stock market, investors often rely on the dividend payment as a perspective to predict the company's future prospects.

Dividend payout policy decision significantly concerns both financial managers in shareholding firms and outside investors. Specially, in Vietnam, securities are still fresh to investors and people alike; and this condition can cause confusion when choosing whether to make buy, hold or sell decisions about stocks. Thus, findings which show how Vietnamese firms' features and corporate governance affect dividend policy will be of real importance to external investors interested in stock market investment in Vietnam. The role and the application of dividend policy are supported by different theories such as signaling theory, trade-off theory, agency theory, transaction cost theory and pecking order theory. Until now, several researchers have continued to prove and developed these theories in order to determine the factors which influence the dividend policy of a joint-stock enterprise. Generally, discussing about dividend payout policy, two main groups of factors are proposed, including firm's characteristics and corporate governance. Firm's characteristics include several factors such as profitability (Fama and French, 2002), firm size (Bebczuk, 2005), debt level (Belden, Fister, and Knapp, 2005), liquidity (Myers and Bacon, 2004), asset structure (Koch and Shenoy, 1999), industry type (Naceur, Goaied, and Belanes, 2006), growth opportunities (Al-Najjar and Hussainey, 2009) and business risk ( $\mathrm{Li}$ and Zhao, 2008). Corporate governance consists of management ownership (Short, Zhang, and Keasey, 2002), ownership concentration (Khan, 2006), board of directors (Bathala and Rao, 1995) and audit quality (Deshmukh, 2005). The factors impacting dividend policy are still remained the subject of debate. Therefore, this study aims to examine the determinants of dividend policy in Vietnam, a developing country with the emerging stock market in Asia.

International study published made for the case of Vietnam is not yet available. There were several researchers who investigated dividend policy in developed countries such as Ramli (2010) discussing about Malaysia. However, just few researchers have done the research about the determinants of dividend policy regarding Vietnam. Also, there are differences existing in dividend payment policy between countries. Some research has only provided dividend policy analysis and 
factors affecting dividend policy. This study provides a more accurate assessment of the factors that influence the dividend policy of listed companies in stock market over a long period of time with the dependent variable measured (dividend payout ratio/dividend per share ratio). Also, this study is based on those assessments to suggest Vietnamese companies to adopt appropriate dividend policy. Finally, this research helps companies how to build their dividend policy to attract foreign investment and how to successfully invest in the Vietnamese stock market. The study is expected to bring out a clear and comprehensive approach of portfolio selection.

\section{Literature Review}

\subsection{School of thought}

Dividend payout policy is always consider as one of the most important policy that a company uses to structure its dividend payout to shareholders and that is also what investors interested in investing a company. The dividend payment may affect directly the interest of shareholders and the rest part of retained profit for future development of a corporate company. Some researchers suggest that dividend policy may be irrelevant in theory, because investors can sell a portion of their shares or portfolio if they need funds.

Based on Miller and Modigliani's (1961) argument, dividend payout policy has been the debatable subject. Dividend payout policy does not affect the value of company, does not influence a company's share price. Miller and Modigliani (1961) indicate that the cost of capital depends on the company's ability to generate income and risks associated with its business rather than the corporate dividend payout policy. On the contrary, some articles of the tax preference theory (Brennan, 1970; Litzenberger and Ramaswamy, 1979; Kalay, 1982; Poterba and Summers, 1984; Miller and Rock, 1985; Ambarish, John, and Williams, 1987) suggest that high dividend payout reduces the value of the company and that dividends are subject to higher tax-cut than capital gains.

On the other hand, the bird-in-hand theory was established based on the saying "a bird in the hand is worth two in the bush." The theory counters the dividend irrelevance theory by Miller and Modigliani (1961) and claim that investors prefer to receive dividends now rather than wait for capital gains in the future." However, Gordon (1962) argued that the cost of capital increases when the payment of dividends is limited. An increase in dividend payments leads to an increase in the value of the company. Gordon (1963) indicated that change in the company's dividend payout ratio would change investors risk level when investing in stocks of company. A high dividend payment corporate would reduce the risk or limit uncertainty about future income flows for shareholders, thus attracting more investors, and vice versa. A high-dividend is paid out by companies to satisfy shareholders' desire for current income. Individuals naturally tend avoid risk in the future and current dividend provide them a sense of security. In short, the behavior of the shareholders would affect dividend policy of the company. 
As for free cash flow theory (Jensen, 1987), one implication is that firms with high levels of free cash flow are more likely to initiate takeovers and investments that are value-decreasing. Managers of firms with excess cash flow will be pressured to pay the excess out to investors as opposed to reinvesting the cash in less profitable opportunities. As payouts to shareholders increase, the stock price will be pushed up. If the firm retains the excess cash, the decreasing marginal utility of the investments available will cause the returns and the stock price to deteriorate. The deterioration of the stock price in a business with free cash flow makes the business an attractive takeover target. This is because there are more profitable uses of the cash (generated by the firm) outside the firm; this cash should be returned to the stockholders to be invested in those more profitable opportunities.

\subsection{Related research in Vietnam}

Alphonse and Tran (2014) conducted a study to investigate dividend policy in Vietnamese stock market with Heckman's two-step regression approach which fixes the selection bias caused by censored research data. Their research findings show that in the first step, likelihood of dividend payment is positively affected by profitability, firm size and earned/contributed capital mix and state control while it is negatively related to investment opportunities, stock liquidity and insider ownership. In the second step, investment opportunities and insider retention have a negative impact on dividend yields while leverage has negative and positive impacts on payout ratio and dividend yield respectively. Contrary to free cash flow hypothesis, free cash flows to total assets ratio is negatively related to payout ratio. Balachandran and Nguyen (2018) explored the factors affecting company's dividend policy such as profitability, firm size, financial leverage and growth rate. The authors have identified two factors - return on total assets and firm size that have a positive and significant effect. Their research results also show a negative impact of enterprise's revenue growth rate on the dividend payment ratio, as well as financial leverage has no impact on company's dividend policy.

Nguyen and Bui (2019) examined the determinants of the dividend policy of nonfinancial companies listed on the Vietnamese stock market for the period 2008-2015 with the binary dependent variable. Their research result shows that profitability, the level of money holdings, the liquidity of stocks and the life cycle of companies play important roles in dividends policy. In addition, growth opportunities and financial leverage also have effects on dividend payments decision. Meanwhile, the other two factors namely the firm size and the risk haven't significantly affect the dividend payout decision.

With these contradictory research results, it is needed to have an explicitly research based on empirical results. In Vietnam, although there have been a number of studies on dividend policy of listed companies in stock market, these research has only provided dividend policy analyzes and factors affecting dividend payout policy. Therefore, our study aims to provide a more accurate assessment of the factors that influence the dividend payout policy of listed companies in stock market over a long 
period of time, measured with the dependent variable (dividend payout ratio, also called as dividend per share ratio). Finally, this study is based on those assessments to suggest Vietnamese companies to adopt appropriate dividend payout policy.

\subsection{Hypotheses development}

\subsubsection{Relationship between profitability and dividend payout ratio}

The financial literature documents that a firm's profitability is a significant and positive explanatory variable of dividend policy (Jensen, 1987; Fama and French, 2002). This factor directly affects the company's dividends payment ability (Lintner, 1956). Companies paying high dividend have high profit (Baker and Wurgler, 2004). In Vietnam, some studies show that return on total assets (ROA) positively affect the company's dividend policy (Nguyen, Nguyen, and Phuong, 2021). The earning per share (EPS) is one of the factors that have a positive influence on the dividend decision. Accordingly, we propose the hypothesis as follows.

H1: Profitability has a positive relationship with dividend policy.

$$
\text { Profitability }(\mathrm{PROF})=\frac{\text { net income }}{\text { Average total assets }}
$$

\subsubsection{Relationship between firm size and dividend payout ratio}

Large companies have an easy access to capital market and a low cost capital mobilization because credit institutions believe their repayment capabilities, so it is unnecessary to use internal funds. Thus, firm size has an inversely relation with the level of internal fund dependence or large company can pay higher dividends (AlShubiri, 2011). Large firms distribute a higher amount of their net profits as cash dividends, more than do small firms (Jensen, 1987; Fama and French, 2002).

As for other studies relative to the findings of positive association between dividends and firm size to transaction costs, for example, Holder, Langrehr, and Hexter (1998) revealed that larger firms have better access to capital markets and find it easier to raise funds at lower costs, allowing them to pay higher dividends to shareholders. Holder, Langrehr, and Hexter (1998) demonstrate a positive association between dividend payouts and firm size. The positive relationship between dividend payout policy and firm size is also supported by a growing number of other studies (Fama and French, 2002; Dahya, McConnell, and Travlos, 2002; Malkawi, 2007). There, we propose;

H2: Firm Size has positive relationship with dividend policy.

Firm Size $($ SIZE $)=$ Ln (revenue) 


\subsubsection{Relationship between financial leverage and dividend payout ratio}

A growing number of studies have found that the level of financial leverage negatively affects dividend policy (Jensen, 1987; Agrawal and Jayaraman, 1994; Faccio, Lang, and Young, 2001; Gugler and Yurtoglu, 2003; Malkawi, 2007). Their studies inferred that highly levered firms look forward to maintaining their internal cash flow to fulfil duties, instead of distributing available cash to shareholders and protect their creditors. However, Mollah (2011) examined an emerging market and found a direct relationship between financial leverage and debt-burden level that increases transaction costs. Thus, firms with high leverage ratios have high transaction costs, and are in a weak position to pay higher dividends to avoid the cost of external financing.

To analyze the extent to which debt can affect dividend payouts, this study employs the financial leverage ratio, or ratio of liabilities (total short-term and long term debt) to total shareholders' equity. The financial leverage shows the total debts over the total liabilities and owners' equity. The higher debts the firms use, the more control by creditors and the more financial risk they may face. Therefore, if the firms have higher financial leverage, the dividend ratio may be lower. This was researched by a lot of economists such as Jensen (1987), Ho (2003), Myers and Bacon (2004), and so on. The firms must spend money and assets to creditor before paying dividend to shareholders. Besides, firms keeping the high debts ratio may reduce the dividend ratio, if they do not want to face to high costs when increasing funds outside. The financial leverage has been measured by the total liabilities over the equity. Thus, this hypothesis is proposed.

H3: Dividend payout is negatively associated with the financial leverage.

Financial leverage $(\mathrm{LEV})=\mathrm{Debt} /$ Total asset

\subsubsection{Relationship between liquidity and dividend payout ratio}

Liquidity ratio is an important class of financial metrics used to determine a debtor's ability to pay off current debt obligations without raising external capital. Liquidity is the extent at which a firm can pay short-term liabilities based on its liquid assets (Atrill and McLaney, 2002). Ho (2003) found that Japan's firms with more liquid have higher dividend payouts. Mehar (2002), however, suggested there is an inverse relationship between liquidity position and dividend payments. From Mehar's study of companies on the Karachi Stock Exchange in Pakistan, firms with positive working capital will lower dividends. Myers and Bacon (2004) highlighted that corporations are likely to lessen dividends to spread liquidity. However, Al-Najjar and Hussainey (2009) proved that paying lower or higher dividends does not depend on a good or bad liquidity position. Since there is still a debate about this association, this study testifies whether the dividend policy of companies in Vietnam is impacted by liquidity. Herewith, we posit the following hypothesis. 
H4: Dividend payout is positively associated with the firm's liquidity.

$$
\text { Liquidity }(\mathrm{CR})=\text { Total cash/Current debt }
$$

\subsubsection{Relationship between Free cash flow and Dividend payout ratio}

Based on the argument of agency problem, Rozeff (1982) develops free cash flow hypothesis stating that dividend payment is a device to mitigate excessive funds which managers can use to invest in negative net present value projects. Holder, Langrehr, and Hexter (1998) initially employ free cash flow to test agency theory with the sample of 477 firms listed in US stock market between 1983 and 1990. Their research findings show firms with higher free cash flows pay lower levels of dividends. Therefore, this study hypothesizes that there is a positive relationship between free cash flow and dividend payout ratio. Therefore, we posit;

H5: Free cash flow is positively related to dividend payout ratio.

Free cash flow $(\mathrm{FCF})=($ Operating income + depreciation - taxes - interest expenses - preferred dividends - ordinary dividends)/Total assets

\subsubsection{Relationship between insider ownership and dividend payout ratio}

Rozeff (1982) posit that insider ownership is a measure of agency costs. Lower insider ownership indicates higher agency costs; therefore, outsiders who hold larger percentage of shares will demand higher dividends to reduce agency costs. Holder, Langrehr, and Hexter (1998) find empirical evidence supporting the negative relationship between the percentage of insider ownership and dividend payments. Based on the arguments mentioned above, we posit;

H6: Insider ownership is negatively related to dividend payout ratio.

Insider ownership (INS): proportion of shares held by insiders.

\subsubsection{Relationship between earnings per share and dividend payout ratio}

As for dividend payout ratio on the earnings per share, Chay and Suh (2009) suggest that this factor has a positive relationship with the dividend payment ratio as firms with a strong cash flow are capable of paying higher dividends as compared to firms with weaker cash flows. Therefore, we posit;

H7: Earnings per share is positively related to dividend payout ratio.

$$
\text { Earnings per share }=\frac{\text { Net Income-Preferred Dividends }}{\text { Weighted Average Common Shares Outstanding }} \text { : }
$$




\subsubsection{Dependent variable: dividend payout ratio}

The dividend payout ratio (DIV) is the proportion of total profit distributed in the form of dividends, the amount that is not pay to shareholder is called retained profit. It is retained by the company to pay off debt. Dividend payout ratio is the number of dividends paid to shareholders on the total net income of a company. Amount of money not to pay dividends to shareholders is retained by the company for investment growth. The money held by the company is called retained earnings. The net income shown in the formula can be found on the company's income statement. This formula is used by some investors when considering whether to invest in a profitable company that pays dividends every year or a profitable company that has high potential for growth. In other words, this formula looks at a stable income with reinvestment for potential future earnings, assuming that the company has an annual net income.

$$
\text { Dividend payout ratio }=\frac{\text { dividends }}{\text { net income }}
$$

\section{Methodology and Data}

\subsection{Methodology}

This study focuses on identifying the factors affect dividend policy of listed companies possible appearance in the Vietnam Stock Market. This research conducts Eviews 8.0 to run the data for analyzing the collected data. This study is explanatory research with a quantitative approach. The data used in this research is the secondary data. Secondary data means that is published or utilized by the other organization. The data is gathered from the official website of Ho Chi Minh Stock Exchange (http://hsx.vn) and company annual report. For additional information, this study also takes a great quantity of information from existed articles, journal papers, text books, etc.

According to the hypotheses development, there are seven variables to be tested including: profitability, firm size, financial leverage, liquidity, free cash flow, insider ownership, and earnings per share. The dependent variable is dividend payout ratio. The relationship among explanatory variables will be tested using Ordinary Least Squares, Fixed Effect model and Random Effect model, regression model to determine the significance, sign and magnitude of the effect of each variable on dividend payout ratio. The multicollinearity of this research objective is detected using the correlation matrix. This study also performs the test to detect the presence of heteroscedasticity or the presence of inconstant variance, in case bias standard errors lead to biased inference of the data, and to make the estimated results of hypothesis possibly inaccurate.

The paper then runs two classes of estimator approaches to determine the model fits of panel data. First, Fixed Effect (FE) model assumes correlation between error term and variables. Second, the Random Effect (RE) model assumes that the variations across the entities are random and uncorrelated with the explanatory variables. RE model also considers the inclusion of the cross section and period. This study 
perform the Hausman test on the panel data set to examine the suitability of either FE model or RE model.

The following regression model is used to test the determinants of dividend payout of the listed companies in Vietnamese stock market:

$$
\begin{gathered}
\mathrm{DPR}_{i t}=\beta_{0}+\beta_{1} \mathrm{PROF}_{i t}+\beta_{2} \mathrm{SIZE}_{i t}-\beta_{3} L E V_{i t}+\beta_{4} C R_{i t}+\beta_{5} F C F_{i t}- \\
\beta_{6} I N S_{i t}-\beta_{7} E P S_{i t}+\varepsilon_{i, t}
\end{gathered}
$$

This research Adopts Ordinary Least Square and Fixed Effect model and Random Effect model. In order to recognize the optimal model consistent with the hypotheses and meanwhile, to explain relationship between variables, we use Hausman test and LikeliHood ratio.

\subsection{Determinants of dividend payout}

This research strongly focuses on investigating the factors to affect possible appearance in the Vietnamese stock market. As the dividend payout ratio is considered as a sign of an investors' return and of a company's future prospect, it is chosen as the dependent variable to explain the factor effect of dividend policy. The variables selected in this research are defined as the Table 3 .

Table 3: Definitions of exploratory variables

\begin{tabular}{|c|c|c|}
\hline Variables & Definition & $\begin{array}{c}\text { Expected sign } \\
\text { of variables }\end{array}$ \\
\hline Profitability & Net income divided by total assets & + \\
\hline Firm size & Ln (revenue) & + \\
\hline Financial leverage & Total Liabilities/ Total Assets & - \\
\hline Liquidity & Current ratio & + \\
\hline Free cash flow & $\begin{array}{c}\text { (Operating income + depreciation - taxes - } \\
\text { interest expenses - preferred } \\
\text { dividends - ordinary dividends)/total assets }\end{array}$ & - \\
\hline Insider ownership & Proportion of shares held by insiders & + \\
\hline Earnings per Share & $\begin{array}{c}\text { (Net income - Preferred Dividends)/Weighted } \\
\text { Average Common Shares Outstanding }\end{array}$ & + \\
\hline
\end{tabular}

\subsection{Data collection}

This study focuses on identifying the factors of affecting dividend policy of listed companies' possible appearance in the Vietnamese Stock Market. The data is collected from listed companies on Ho Chi Minh Stock Market for 5 years (20142018) with 756 observations (unbalanced data) and the regression model is based on panel data. This research collects financial statements, which include balance sheet and income statement of listed companies in the Ho Chi Minh Stock Exchange 
(http://hsx.vn). All financial and accounting data are gathered from the databank of Ho Chi Minh Stock Exchange (HOSE) as well as the source supplied of VnDirect website (http://vndirect.com.vn). The data are gathered from balance sheet, financial statement, etc. of listed company in Ho Chi Minh Stock Exchange from the data (2014-2018).

\section{Empirical Results}

\subsection{Descriptive statistic}

This research used the statistical program EViews 8.0 to run the Testing from sample observation. Table 4 shows the descriptive statistics for listed firms in the Ho Chi Minh Stock Exchange (HOSE); it is clear to observe the average dividend payout ratio (39.68\%) of the 754 listed companies during $2014-2018$ with a standard deviation of $31.02 \%$. This means, on average, the listed companies on the Ho Chi Minh Stock Market spent $39.68 \%$ of their net profit to pay dividends.

Table 4: Descriptive statistic of variables -HOSE

\begin{tabular}{|c|c|c|c|c|c|c|}
\hline Variable & Mean & Median & Std. Dev & Min & Max & Objs \\
\hline PROF & 0.0674 & 0.05 & 0.0907 & -0.5 & 0.9549 & 754 \\
\hline SIZE & 12.8511 & 12.7533 & 1.7251 & 7.2049 & 16.5967 & 754 \\
\hline LEV & 0.1403 & 0.1211 & 0.4967 & 0 & 6.7343 & 754 \\
\hline CR & 2.7669 & 1.5451 & 4.5828 & 0.0053 & 48.1437 & 754 \\
\hline FCF & 5.6691 & 2.3345 & 9.1896 & -0.9608 & 78.2727 & 754 \\
\hline INS & 0.2407 & 0.1333 & 0.3238 & 0 & 3.4228 & 754 \\
\hline EPS & 0.4417 & 0 & 6.3322 & -63.54 & 154.33 & 754 \\
\hline DIV & 0.3968 & 0.3908 & 0.3102 & 0 & 2.4775 & 754 \\
\hline
\end{tabular}

Source: data extracted from financial statement and calculated from EViews 8.0

Note: 1. Dependent variable (DIV) denotes Dividend Payout Ratio. 2. The controlling variable PROF denotes return on asset in the year, SIZE denotes firm size (natural log of total asset); LEV denotes long-term debt / total asset ratio; CR mean current ratio; FCF denotes free cash flow/ total asset; INS denotes insider ownership; EPS denotes the earning/per share ratio.

Table 4 illustrates that a fluctuation gap of the dividend payout ratio of listed companies in the HOSE is quite large with a maximum value of $247 \%$ and a minimum value of $0 \%$. Additionally, the Table 4 describes the average value, standard deviation and fluctuation gap of seven independent variables. Average ROA - PROF is $6.80 \%$. The logarithm of total revenue (SIZE) is $12.85 \%$, average Financial Leverage (LEV) is $14.03 \%$ and average free cash flow (FCF) is $5.67 \%$. Businesses usually pay cash dividends from 1-2 times a year, but in particular there are companies paying cash dividends 5 times a year. Average ROA is $6.80 \%$. Examining the LEV, it may recognize that the ratio is not too high on average at $14.03 \%$ only; this means that the listed companies are willing to raise the fund in the equity market, instead of borrowing money from banks or other financial institutions. 


\subsection{Correlation analysis}

As for the Ho Chi Minh sample, Table 5 describes the correlation coefficients among the variables of listed companies in the HOSE. Most of the independent variables have a low correlation with the others, but represent quite high correlations between FCF and PROF, LEV and SIZE, CR and PROF (0.11618; 0.11016; 0.129091 respectively) that may cause the multicollinearity in the model. However, this sign has an insignificant effect on the regression model in general. Therefore, most of the independent variables have no strong correlation and show a good sign to test the model in the next section. All of the key explaining for the hypothesis development (PROF, SIZE, LEV, FCF, INS) are significant at $10 \%$ level and most of them positively related to the dividend payout ratio. The dependent variable DIV have a correlation relationship with PROF, SIZE, LEV, FCF, INS at the 0.01 level and 0.05 level.

Table 5: Correlation coefficients matrix -HOSE

\begin{tabular}{|c|c|c|c|c|c|c|c|c|}
\hline & DIV & PROF & SIZE & LEV & CR & FCF & INS & EPS \\
\hline DIV & 1 & & & & & & & \\
\hline PROF & $0.109351^{*}$ & 1 & & & & & & \\
\hline SIZE & $-0.086347^{*}$ & -0.010298 & 1 & & & & & \\
\hline LEV & $-0.108237^{*}$ & $-0.118413^{*}$ & $0.110613^{*}$ & 1 & & & & \\
\hline CR & 0.055696 & $0.129091^{*}$ & -0.048028 & -0.051193 & 1 & & & \\
\hline FCF & $0.08555^{*}$ & $0.11618^{*}$ & -0.032861 & $-0.095386^{*}$ & 0.053952 & 1 & & \\
\hline INS & $-0.07046^{* *}$ & -0.044088 & $-0.081964^{*}$ & -0.034027 & 0.012526 & -0.010087 & 1 & \\
\hline EPS & -0.047589 & 0.014525 & -0.05754 & $0.093133^{*}$ & -0.011026 & -0.016095 & -0.045791 & 1 \\
\hline
\end{tabular}

Source: data extracted from financial statements and calculated from EViews 8.0

Note: 1.Dependent variable (DIV) denotes Dividend Payout Ratio. 2. The controlling variable PROF denotes return on asset in the year, SIZE denotes firm size (natural log of total asset); LEV denotes long-term debt / total asset ratio; CR mean current ratio; FCF denotes free cash flow/ total asset; INS denotes insider ownership; EPS denotes the earning/per share ratio.

\section{Relationship between DIV and profitability (PROF)}

The dividend payout ratio has a significant correlation with profit. The value is 0.109351 that means a positive and significant correlation between two variables, but it is weak. This implicates that when ROA increases, DPR will increases. According to the research assumption, firms with high and stable profitability may have a strong cash flow to pay dividends. H1 is supported.

\section{Relationship between DIV and firm size (SIZE)}

Table 5 shows the value correlation (-0.086347) between dividend payout ratio and firm size. This result means that a negative relationship exists between them which is actually in contrast with $\mathrm{H} 2$ of firm size being positively related to dividend payout policy. 


\section{Relationship between DIV and finance leverage (LEV)}

The dividend payout ratio of the company in HOSE has a negative relationship with finance leverage. The value is -0.108237 which means a negative correlation between two variable. This result is consistent with $\mathrm{H} 3$. The higher debts the firms use, the more control by creditors and the more financial risk they may face. Leverage can also refer to the amount of debt a firm uses to finance assets. If a firm is described as highly leveraged, the firm has more debt than equity. Therefore, if the firms have higher financial leverage, the dividend ratio may be lower.

\section{Relationship between DIV and firm's liquidity (CR)}

As shown in Table 5, the correlation relationship value indicates that there are positive relationship and significant at 0.01 level. Therefore, $\mathrm{H} 4$ is supported. The correlation coefficients matrix among variables is used to analyze and examine the probability of multicollinearity occurrence. Based on the data on Table 5, the likelihood of multicollinearity in the regression model is small because most of the correlations among variables are relatively small. None of the cases have the absolute value exceeding 0.6.

\section{Relationship between DIV and free cash flow (FCF)}

The dividend payout ratio has positive relationship and significant with free cash flow variable. The value is 0.0855 which means that dividend payout increases while free cash flow of the company increases. H5 is supported.

\section{Relationship between DIV and insider ownership (INS)}

Table 5 shows that dividend payout ratio and insider ownership have a negative relationship with the value -0.007046 at significant 0.01 level. This result is consistent with H6. When the firm have a larger number insider shareholder, it pays less dividend.

\section{Relationship between DIV and earning per share (ESP)}

Table 5 shows the value correlation (-0.047589) between dividend payout ratio and earning per share. This result means that a negative relationship exists between them which is actually in contrast with $\mathrm{H} 7$ of earning per share being positively related to dividend payout policy.

Durbin Watson test is used for checking the autocorrelation for unbalanced panel data. The Durbin-Watson test statistic tests the null hypothesis that the residuals from an ordinary least-squares regression are not autocorrelated against the alternative that the residuals follow an AR1 process. The Durbin Watson test statistic value is 1.415 that means no autocorrelation detected in this sample. The results of this study is more exactly (see Table 6). 
Table 6: Durbin Watson test results for autocorrelation

\begin{tabular}{|c|c|c|c|c|}
\hline \multicolumn{5}{|c|}{ Model Summary } \\
\hline Model & R square & Adj R Square & Std. Error & Durbin Watson \\
\hline Fem & 0.0399 & 0.0309 & 0.305 & 1.415 \\
\hline Independent variable: PROF, SIZE, LEV, CR, FCF, INS, EPS \\
\hline \multicolumn{4}{|l}{ Dependent variable: DIV }
\end{tabular}

\subsection{Empirical Results}

According to Arellano (1987), for the term of fixed T, it is a common practice to use the White period estimator in favor of the White cross section or the White diagonal estimator. Thus, in this research, the coefficient covariance method has been chosen as the White period. Using the Likelihood Model for cross-section Ftest, the Prob lower than 0.01 indicates that the effects option of panel data should be used instead of Pooled OLS (Table 7).

Table 7: Result of the LikeliHood test

\begin{tabular}{|c|c|c|}
\hline Test summary & Statistic & Prob \\
\hline F & 2.867722 & 0.0000 \\
\hline Chi - Square & 422.885094 & 0.0000 \\
\hline
\end{tabular}

Table 8: Result of the Hausman test

\begin{tabular}{|c|c|c|c|}
\hline Test summary & Chi-Sq Statistic & Chi-Sq .d. f & Prob \\
\hline Cross section random & 12.253394 & 7 & 0.0925 \\
\hline
\end{tabular}

The Hausman Specification Test is used for choosing between the Fixed Effect model and Random Effect model with hypotheses: H0: Random Effect Model is appropriate; H1: Fixed Effect model is appropriate. Because based on the result of the Hausman Specification Test with the p value is 0.0925 and Chi Square > Prob. So the hypotheses $\mathrm{H} 0$ is rejected (see Table 8).

This research shows three models: Pooled OLS, FEM and REM, in which the REM is not appropriate to explain the changes of DPR. Therefore, the LikeliHood test is conducted to choose one proper method between Pooled OLS and FEM. The null hypothesis is "the Pooled OLS is appropriate". The P-value, which is approximately $0 \%$, proves that the null hypothesis is rejected and the Fixed Effect Model is chosen. The result of FEM points out that there 5 factors including the financial leverage, return on asset and firm size, free cash flow and insider ownership among 7 factors having a significant relationship with the dividend payout ratio of listed companies in the HOSE. Specifically, as can be seen from the result that the coefficient of the 
EPS variable is approximately $0(-0.0025)$, this factor is not statistically significant with the DPR. And the value of the liquidity is 0.0022 is also approximately 0 which shows that this liquidity variable is not statistically significant with dividend payout ratio (Table 9).

Table 9: Results based on OLS, FE Model, RE Model (2014-2018)

\begin{tabular}{|c|c|c|c|c|}
\hline & OLS & FEM & REM & $\operatorname{Obs}(\mathrm{N})$ \\
\hline \multirow[t]{2}{*}{ PROF } & 0.2898 & 0.2906 & 0.1726 & 756 \\
\hline & $(0.0208) * *$ & $(0.0208) * *$ & $(0.2229)$ & 756 \\
\hline \multirow[t]{2}{*}{ SIZE } & -0.0147 & -0.0149 & -0.0112 & 756 \\
\hline & $(0.0238) * *$ & $(0.0228)^{* *}$ & $(0.1718)$ & 756 \\
\hline \multirow[t]{2}{*}{ LEV } & -0.0497 & -0.0495 & -0.0412 & 756 \\
\hline & $(0.0301)^{* *}$ & $(0.0315)^{* *}$ & $(0.0734)^{*}$ & 756 \\
\hline \multirow[t]{2}{*}{$\mathbf{C R}$} & 0.0022 & 0.0022 & 0.0019 & 756 \\
\hline & $(0.3505)$ & $(0.3665)$ & $(0.4434)$ & 756 \\
\hline \multirow[t]{2}{*}{ FCF } & 0.0020 & 0.0021 & 0.0006 & 756 \\
\hline & $(0.0874)^{*}$ & $(0.0826)^{*}$ & $(0.6256)$ & 756 \\
\hline \multirow[t]{2}{*}{ INS } & -0.0748 & -0.0726 & -0.0893 & 756 \\
\hline & $(0.0304) * *$ & $(0.0363) * *$ & $(0.0457) * *$ & 756 \\
\hline \multirow[t]{2}{*}{ EPS } & -0.0023 & -0.0025 & -0.0026 & 756 \\
\hline & $(0.1812)$ & $(0.1556)$ & $(0.1029)^{*}$ & 756 \\
\hline Cons & 0.5750 & 0.5767 & 0.5477 & 756 \\
\hline R-square & 0.041 & 0.043 & 0.019 & 756 \\
\hline Adj R-square & 0.039 & 0.029 & 0.009 & 756 \\
\hline
\end{tabular}

$*, * *$ and $* * *$ are significance at 10,5 and 1\% levels, respectively; $\mathrm{p}$-values are in parentheses.

Source: data extracted from financial statements and calculated from EViews 8.0

Note: 1.The dependent variable DIV denotes Dividend Payout Ratio. 2. The controlling variable PROF denotes return on asset in the year, SIZE denotes firm size (natural log of total asset); LEV denotes long-term debt / total asset ratio; CR mean current ratio; FCF denotes free cash flow/ total asset; INS denotes insider ownership; EPS denotes the earning/per share ratio

In dividend policy studies, depending on the availability of data, only a few basic factors can be considered in many different factors. So R-square result is low that is a common result (Gill, Biger, and Tibrewala, 2010; Bistrova and Lace, 2012). The adjusted R-squared is a modified version of $\mathrm{R}$-squared that adjusts for predictors that are not significant in a regression model. Compared to a model with additional input variables, a lower adjusted R-squared indicates that the additional input variables are not adding value to the model. The adjusted R-squared values of this analysis are $0.039,0.029$, and 0.009 respectively. The low $\mathrm{R}$ square value 
suggests that there are other factors that affect the dividend policy of Vietnamese companies have not been put in the model yet. We have to consider many factors including tax, business risks, turnover ratio, etc. which do not have official data in Vietnam yet or are factors that do not change over time such as industry or owner. Table 9 shows the determinants of dividend payout policy to test for the precision of Hypotheses. The larger firms with better accounting performance on asset are likely to pay lower dividend. With the negative coefficient in financial leverage variable, the small leverage companies seems to pay higher dividend. Analyzing the hypotheses testing for the determinants of dividend payout ratio, the results are mostly consistent with research's hypothesis. As of my hypotheses assumption, companies with high profitability, high concentrated ownership, and high free cash flow tend to distribute higher ratio of dividend. The firm size variable (SIZE), which represents total asset of all listed companies in HOSE, has negative relationship with dividend payout ratio based on both the Pooled OLS and the Fixed Effect model. This result is contrast with the hypothesis proposed in this research. However this value is statistically significant at 0.05 level. This means firm size variable has an impact to the dividend policy. This result shows that large-sized firms prefer to pay less dividend. Therefore, we fail to reject the null hypothesis that size has negative relationship with dividend payout. Some literature come up with contradictory evidence (e.g., Mirza and Azfa, 2010). Large enterprises have easy access to capital markets and mobilize capital with low fees and interests. Because creditors, banks believe the repayment of the companies, they don't necessarily use internal capital

Company profitability (PROF)-ROA is positively associated with dividend payout ratio. This result is consistent with our hypothesis. This shows that firms with high profits used it as signaling device for future performance. A firm's profitability is considered an important factor in influencing dividend payment policy. This result supports the life cycle theory which explains that mature firms with more profit can pay more dividends. Herewith, the findings of this study support $\mathrm{H} 1$ consistent with Musah, Senyo, and Nuhu (2014). The profitability has a positive impact on the dividend policy of company listed on the securities market of Vietnam. This result explains that companies with good profitability pay dividends to shareholders. The previous dividend policy has a positive impact on the dividend policy of the next period, however, the company size does not affect the dividend policy.

As for free cash flow (FCF), the regression coefficient of this variable is positive under the Pooled OLS and Fixed Effect model, which is actually consistent with this study's hypothesis. As expected, the results indicate significant positive relationship between free cash flow and dividend payout ratio. The results of this study suggest that firm with good and stable cash flow are able to pay dividend easily compared with firms with unstable cash flow position. Financial leverage has a negative impact on dividend policy of enterprises listed on the securities market of Vietnam. This can be explained that the higher the debt rate is higher the risk. When the cost of capital is high, the business must pay attention to the debt payment rather than dividends payment. 
Regarding insider ownership, the regression coefficient of this variable is negative and significant under the Pooled OLS and Fixed Effect model, which is actually consistent with the paper's hypothesis. Because Vietnam is the new market, information asymmetry between management (internal) and investors (external) whereby investors are hard to gather the comprehensive information and acquire less knowledge about the company's management decision. Therefore, they may not appreciate the stock and make excessive sell-offs that reduce the share price.

As to financial liquidity and earning per share, the results of this study indicate that financial liquidity has positive impact with dividend payout ratio but insignificant. And earning per share variable which has negative impact and significant relationship with dividend payout ratio. The relationship between the firm's liquidity and dividend payout ratio is positive which explains that firms with more market liquidity pay more dividends. Ahmed and Javid (2008) have come up with the same conclusion. However, some literature find the opposite evidence (Reddy and Rath, 2005; Amidu and Abor, 2006).

As shown in Table 9, the FE model indicates that PROF is significant and positively related to DPR. This explains that when ROA increases by $1 \%$, DIV increases by $0.29 \%$. According to the research assumption, firms with high and stable profitability may have a strong cash flow to pay dividends. Therefore, this result explains based on the pecking order theory that firms intends to retain more earnings to avoid high costs, and also explains the higher the profit of firms, the lower the dividends. The model indicates that LEV has a negative and statistically significant relationship with DIV. When financial leverage increases by $1 \%$, DPR decreases by $0.004 \%$. This result expects with the research prediction from the perspective of transaction cost theory. According to transaction cost theory, firms with high financial leverage tend to reduce the dividend payments to avoid high transaction costs and the other costs. However, the value of the LEV's beta is quite small which means that the effect on the dividend payout ratio of leverage is not significant as previously expected.

The first econometric model that has been used to deal with the panel data is Pooled Ordinary Least Square (Pooled OLS). This model tests how the independent variables affect the dependent variable with assumptions. Among the seven explanatory variables, five variables have a statistical effect on the dividend payout ratio at the significant at $5 \%$ level. In order to choosing the model of this study which consistent with my hypotheses and clear explain about the relationship between seven independent variables and dependent variable dividend payout ratio, this study uses LikeliHood ratio and Hausman Specification Test. Hausman Specification Test result shows that there are $\mathrm{p}$-value is approximately $0 \%$ smaller than 5\%, so that he Fixed Effect model is the relevant model. Finally, this study chooses the Fixed Effect model with the largest LikeliHood value. The Fixed Effect model with seven variables is the chosen model to study (Table 9). The regression with the Fixed Effect model is illustrated in Table 9. This means the Fixed Effect model can be chosen as the independent variables and may explain the change of the dependent variable (DIV). To estimate the appropriation of beta coefficients 
individually, this study continues to compare each $\mathrm{P}$-value with 5\%. The null hypothesis is " $\beta \mathrm{i}=0$ " (with $\mathrm{i}=[1 ; 10]$ ). If the $\mathrm{P}$-value is greater than $5 \%$, the null hypothesis cannot be rejected.

In comparing the results of the Fixed Effect model and Random Effect model, this research favors the results of the FE model as the better fitting model because the p-value of LikeliHood is $0<0.05$. Based on the Hausman Specification Test result, Random Effect model is not appropriate. However, as the observation period 5 year is much smaller than the cross section with around 754 sample firms. This is insufficient for applying the Period Fixed Effect. Thus make this study uses the Cross-section Fixed Effect for testing the coefficient between the explanatory variables.

In conclusion, the result emphasizes the relevance on dividend payout policy, which importantly contributes to better understand the behavior practice of the listed companies in the Ho Chi Minh stock Exchange. Thus, this study is not only provide important policy lesson for the market controllers and the regulation issuers, but also apply a further view for investors in decision making. In short, dividend payout policy is the most important indicator for investors and financial managers of the firms.

\section{Conclusion and Limitations}

\subsection{Discussion}

This research examines whether the eight factors determined, namely: profitability, firm size, finance leverage, liquidity, insider ownership, earning per share and free cash flow affect the dividend payout policy of listed companies in Ho Chi Minh Stock Market. Three types of models are Pooled OLS, Fixed Effect Model and Random Effect Model to find out specific relationship and characteristics of each variable with dividend payout policy of the company. This study has already considered the dividend policy is one of the most debatable topics in corporate finance and it is one of the most important decisions of financial management. Dividend policy provides the information content for investors in the stock market to making investment decisions. Information on the dividend policy of the listed companies show the presence of factors affecting the company's policy to distribute the dividend significantly and insignificantly for the decisions of financial management of the Vietnam security market. The results of this research will help the investors that their forecasts should be more accurate and making investment decisions. Companies with large investment needs but limited access to capital will give higher priority to retaining reinvestment profits to meet growth needs. Companies that are heavily indebted, high debt ratios often pay low dividends to prioritize debt financing. For most small and medium-sized companies in the Vietnamese economy, accessing capital from banks or issuing shares is not easy, so these companies often have to rely more on Endogenous capital is the retained earnings, so they often pay low dividends or don't pay dividends.

Generally, findings of this study are in-line with previous empirical evidences. 
Based on the analysis of the factors that affect the companies' dividend policy of the listed companies for the period of 2014-2018, it can be concluded that during the period of observation, the variables of debt to equity ratio, return on assets, firm size, financial leverage, free cash flow, inside ownership have significant influence while the variable of current ratio and earning per share has effect but not significant toward dividend payout ratio on the listed companies

The results of this study prove positive significant impact of profitability, return on asset with dividend payout policy. Positive significant impact of return of asset shows that ROA is an indicator of how profitable a company is relative to its total assets. ROA gives a manager, investor, or analyst an idea as to how efficient a company's management is at using its assets to generate earnings. About firm size factor, it has a negative related with the decision making dividend policy. Negative significant impact of the firm size show that the large size company pay low dividends. In fact, for most small and medium-sized companies in the Vietnamese economy, accessing capital from banks or issuing shares is not easy, so these companies often have to rely more on Endogenous capital is the retained earnings, so they often pay low dividends or don't pay dividends. And the large listed joint stock companies have better access to capital than small businesses, so they often pursue a policy of dividend stabilization. Dividend stabilization policy is a policy pursued by the majority of listed companies because this policy has the advantage of creating a stable cash flow for shareholders, stabilizing shareholder psychology and helping stock prices of the company are appreciated. About financial leverage, this study proved negative significant of the company leverage with dividend payout policy. Negative significant impact of financial leverage show that the higher the debt rate is higher the risk. When the cost of capital is high, the business must pay attention to the debt payment rather than dividends payment.

Based on the results of this study, the author propose some recommendations: Investors need to study the financial status of the business as the profitability because it will affect to the dividends payment of the next period. High debt ratio will negatively affect dividend payment. The manager should have an analysis of the advantages and disadvantages of each type of dividend policy and consider which one will be suitable with the specific characteristics of company. Most importantly, managers have a clear choice of dividends policy and pursue that choice. Because, in order to maintain dividend payments, it is imperative for managers to have a long-term financial and investment strategy, a more responsible for raising capital efficiency, helping to increase the company value in the long run. Enterprises should prioritize stable dividend policy to maintain a certain level of dividends and increase dividends to a higher level only in the case that the company can achieve a stable increased profitability and have an ability to increase dividend. Once the dividend has been increased, company must try to maintain this dividend level until the company recognizes that there is no hope to prevent a decline in profitability in the future. 


\subsection{Limitation and future research}

Although, the study provides a considerable amount of contribution, there still exist some limitations and suggested future studies to be improves in next researches. Author realizes that the study has limitations of data, the data in this research is collected from listed companies in Ho Chi Minh Stock Market in the period from 2014-2018, five year is the period not enough long time to be finding the change in the Ho Chi Minh stock market, further research can be carried out with the addition of the study period in analyzing the factors that affect the listed companies' dividend policies. Because the Vietnamese stock market has just developed in recent years, that the reason why the data used in this study is limited to medium and large company listed on the Ho Chi Minh Stock Exchange, southern of Vietnam, so the results are not yet able to be applied in all companies Vietnam. Future studies are suggested to increase the data span and cover all of the Ha Noi stock Exchange not included in this study. Most of Ho Chi Minh stock Exchange listed companies are still not publicly. Future studies also attempt to investigate the factors affecting the decisions making dividend payout policy and extend the number of significant determinants. Regardless of these limitations, this study provides a good perspective to the investors and financial management, and is also helpful for Vietnamese investors and financial managers who examine factors affecting the company's dividend payout policy in making investment decision.

\section{References}

[1] Agrawal, A. and Jayaraman, N. (1994). The dividend policies of all-equity firms: A direct test of the free cash flow theory. Managerial and Decision Economics, 15(2), pp. 139-148.

[2] Ahmed, H. and Javid, A.Y. (2008). The determinants of dividend policy in Pakistan. International Research Journal of Finance and Economics, 29, pp. 110-125.

[3] Al-Malkawi, H.A.N. (2007). Determinants of corporate dividend policy in Jordan: an application of the Tobit model. Journal of Economic and Administrative Sciences, 23(2), pp. 44- 70.

[4] Al-Najjar, B. and Hussainey, K. (2009). The association between dividend payout and outside directorships. Journal of Applied Accounting Research, 10(1), pp. 4-19.

[5] Alphonse, P. and Tran, Q.T. (2014). A two-step Approach to investigate dividend policy: evidence from Vietnamese stock market. International Journal of Economics and Finance, 6(3), pp. 1916-1928.

[6] Al-Shubiri, F.N. (2011). Capital structure and market power: evidence from Jordanian banks. Managing Global Transitions, 9(3), pp. 289-310.

[7] Ambarish, R., John, K., and Williams, J. (1987). Efficient signalling with dividends and investments. The Journal of Finance, 42(2), pp. 321-343.

[8] Amidu, M. and Abor, J. (2006). Determinants of dividend payout ratios in Ghana. The Journal of Risk Finance, 7(2), pp. 135-145. 
[9] Atrill, P. and McLaney, E. (2002). Management Accounting for Nonspecialists. Pearson Higher Education.

[10] Arellano, M. (1987). Computing robust standard errors for within-groups estimators. Oxford Bulletin of Economics and Statistics, 49(4), pp. 431-434.

[11] Baker, M and Wurgler, J. (2004). A catering theory of dividends. Journal of Finance, 59(3), pp. 1125-1165.

[12] Balachandran, B. and Nguyen, J.H. (2018). Does carbon risk matter in firm dividend policy? Evidence from a quasi-natural experiment in an imputation environment. Journal of Banking \& Finance, 96, pp. 249-267.

[13] Bathala, C.T. and Rao, R.P. (1995). The determinants of board composition: an agency theory perspective. Managerial and Decision Economics, 16(1), pp. 59-69.

[14] Bebczuk, R.N. (2005). Corporate governance and ownership: measurement and impact on corporate performance and dividend policies in Argentina. (Working Paper, Documentos de Trabajo; No. 59). Center for Financial Stability, National University of La Plata, Argentina.

[15] Belden, S., Fister, T. and Knapp, B. (2005). Dividends and directors: do outsiders reduce agency costs? Business and Society Review, 110(2), pp. 171180.

[16] Bistrova, J. and Lace, N. (2012). Quality of corporate governance system and quality of reported earnings: evidence from CEE companies. Economics and Management, 17(1), pp. 55-61.

[17] Brennan, M.J. (1970). Taxes, market valuation and corporate financial policy. National Tax Journal, 23(4), pp. 417-427.

[18] Chay, J. B. and Suh, J. (2009). Payout policy and cash-flow uncertainty. Journal of Financial Economics, 93(1), pp. 88-107.

[19] Dahya, J., McConnell, J. J., and Travlos, N.G. (2002). The Cadbury committee, corporate performance, and top management turnover. The Journal of Finance, 57(1), pp. 461-483.

[20] Deshmukh, S. (2005). The effect of asymmetric information on dividend policy. Quarterly Journal of Business and Economics, 44(1), pp. 107-127.

[21] Faccio, M., Lang, L.H., and Young, L. (2001). Dividends and expropriation. American Economic Review, 91(1), pp. 54-78.

[22] Fama, E.F. and French, K.R. (2002). Testing trade-off and pecking order predictions about dividends and debt. The Review of Financial Studies, 15(1), pp. 1-33.

[23] Gill, A., Biger, N., and Tibrewala, R. (2010). Determinants of dividend payout ratios: evidence from United States. The Open Business Journal, 3, pp. 8-14.

[24] Gordon, M.J. (1962). The savings investment and valuation of a corporation. The Review of Economics and Statistics, 44, pp. 37-51.

[25] Gordon, M. J. (1963). Optimal investment and financing policy. Journal of finance, 18(2), pp. 264-272.

[26] Gugler, K. and Yurtoglu, B.B. (2003). Corporate governance and dividend pay-out policy in Germany. European Economic Review, 47(4), pp. 731-758. 
[27] Ho, H. (2003). Dividend policies in Australia and Japan. International Advances in Economic Research, 9(2), pp. 91-100.

[28] Holder, M.E., Langrehr, F.W and Hexter, J.L. (1998). Dividend policy determinants: An investigation of the influences of stakeholder theory. The Journal of the Financial Management Association, 27(3), pp. 73-85.

[29] Jensen, M.C. (1987). The free cash flow theory of takeovers: a financial perspective on mergers and acquisitions and the economy. In Proceedings of a conference sponsored by Federal Reserve Bank of Boston (pp. 102-143).

[30] Kalay, A. (1982). The ex-dividend day behavior of stock prices: a reexamination of the clientele effect. The Journal of Finance, 37(4), pp. 10591070.

[31] Khan, T. (2006). Company dividends and ownership structure: evidence from UK panel data. The Economic Journal, 116(510), pp. C172-C189.

[32] Koch, P.D. and Shenoy, C. (1999). The information content of dividend and capital structure policies. Financial Management, 28(4), pp. 16-35.

[33] Li, K. and Zhao, X. (2008). Asymmetric information and dividend policy. Financial Management, 37(4), pp. 673-694.

[34] Lintner, J. (1956). Distribution of incomes of corporations among dividends, retained earnings, and taxes. The American Economic Review, 46(2), pp. 97113.

[35] Litzenberger, R.H. and Ramaswamy, K. (1979). The effect of personal taxes and dividends on capital asset prices: theory and empirical evidence. Journal of Financial Economics, 7(2), pp. 163-195.

[36] Mehar, A. (2002). Corporate governance and dividend policy. Pakistan Economic and Social Review, XLIII(1), pp. 115-128.

[37] Miller, M and Modigliani, F. (1961). Dividend policy, growth, and the valuation of shares. Journal of Business, 34, pp. 411-433.

[38] Miller, M.H. and Rock, K. (1985). Dividend policy under asymmetric information. The Journal of Finance, 40(4), pp. 1031-1051.

[39] Mirza, H.H. and Azfa, T. (2010). Ownership structure and cash flows as determinants of corporate dividend policy in Pakistan. International Business Research, 3(3), pp. 210-221.

[40] Mollah, S. (2011). Do emerging market firms follow different dividend policies? Empirical investigation on the pre-and post-reform dividend policy and behaviour of Dhaka Stock Exchange listed firms. Studies in Economics and Finance.

[41] Musah, A., Senyo, D., and Nuhu, E. (2014). Market timing and selectivity performance of mutual funds in Ghana. Management Science Letters, 4(7), pp. 1361-1368.

[42] Myers, M. and Bacon, F. (2004). The determinants of corporate dividend policy. Academy of Accounting and Financial Studies Journal, 8(3), pp. 17-28.

[43] Naceur, S.B., Goaied, M., and Belanes, A. (2006). On the determinants and dynamics of dividend policy. International Review of Finance, 6(1-2), pp. 123. 
[44] Nguyen, D., To, T.H., Nguyen, D.V., and Phuong, D.H. (2021). Managerial overconfidence and dividend policy in Vietnamese enterprises. Cogent Economics \& Finance, 9(1), p. 1885195.

[45] Nguyen, T.T.N. and Bui, P.K. (2019). Dividend policy and earnings quality in Vietnam. Journal of Asian Business and Economic Studies, 26(2). pp. 301-312.

[46] Poterba, J.M. and Summers, L.H. (1984). The economic effects of dividend taxation (No. w1353). Working paper, National Bureau of Economic Research.

[47] Ramli, N.M. (2010). Ownership structure and dividend policy: evidence from Malaysian companies. International Review of Business Research Papers, 6(1), pp. 170-180.

[48] Reddy, Y. S. and Rath, S. (2005). Disappearing dividends in emerging markets? Evidence from India. Emerging Markets Finance and Trade, 41(6), pp. 58-82.

[49] Rozeff, M.S. (1982). Growth, beta and agency costs as determinants of dividend payout ratios. Journal of financial Research, 5(3), 249-259.

[50] Short, H., Zhang, H. and Keasey, K. (2002). The link between dividend policy and institutional ownership. Journal of Corporate Finance, 8(2), pp. 105-122.

[51] Sierpińska, M. and Jachna, T. (2007). Financial Decision-making MethodsAnalysis of Examples and Cases, ed. OWN, Warsaw. 